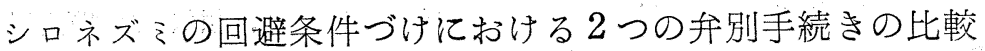

\author{
早稲田大学文学部 春 木豊・石井 文一郎
}

\section{問題}

回避条件づけは古典的条件づけの原理では説明できないということで種々なる理論は一 致している (平井・春木・酒井，5)。例光ばMOWRER や MILLER の説明に従うならば, 回避反応法 2 次性動因である不安によって動機づけられており, 条件づけが成立した後に は，CSが２次性動因価を消失しない限りUCSなしでも反応が持続し，また新しい反応を 習得することもできるというものである。この理論に基ゔき，回避条件ゔけの習得や消去 についての特有な現象については多数の分析がなされている。また回避条件づけの汎化に ついてはMILLER \& GREENe (9), 宮田 (10), Thompson (12), Hoffeld (6) 等の報告 があり，いずれも回避条件づけの機制が特有な機制を有しているものであるにも拘らず， 現象的に古典的条件うけにおける沉化と同一のものがみられること示している。

回避条件づけの弁別については赤松・平井・春木（1）の報告があり，弁別は正刺激と 負刺激との類似度によって強く影響され，類似度が低いならば弁別は成立するし，成立の 経過も古典的条件づけの場合と異ならないが，類似度が高いと成立しにくいことを示した。 また赤松・平井・春木 $(2)$ は強化に用いるUCS の強度についてはこの場合あまり効果が ないことも明らかにした。また春木・平井（4）注回避条件づけの弁別は刺激の類似度の みによって弁別の難易がきめられるばかりでなく, 上記のような回避条件づけの機制から 推論して他の条件づけの場合と比較して困難である䈏であり，特有な手続きを用いなけれ ばならないことを示した。

PAVLOV (11) 法古典的条件うけの分化について説明し, 識別困難な類似した刺激の間の 分化を成立させるためには, 最初から類似した刺激を用いて分化手続きを行うょりも, 最 初は類似度の低い刺激の間の分化を行わせ, 徐々飞類似した刺激へと近づけて行く方法を 用いると分化がよりよく成立しやすいと述べている。

LAWRENCE (7) は道具的条件づけでもこの事実のあることを確めている。すなわち, 明 るさの同時比較の升別において, 非常に類似した刺激の間の弁別を最初から行わせる場合 と, 最初は非常に異なった刺激の間の升別を何回か行い，その後急に類似した刺激の弁別 它行わせる場合と, 最初は非常に異なった刺激の間の弁别から出発し, 徐々に類似した刺 激へと近つけて行く場合の 3 つの方法について并別の成立の程度を比較した。その結果, 最初から識別困離な刺激の間の弁别を行わせるよりも，最初は識別容易な刺激の弁別から 始まって徐々に類似た刺激へと近づけて行く方法が最も弁別の成立がよいことを示した。 そこで, 本実験では理論的に升别が困離であると推論される回避条件べけの弁別をいか 
に容易によりよく成立せしめ得るかについて考察するに当って，類似した刺激を用いた回 避条件づけの弁別の成立に PAVLOV-LAWRENCE の弁別手続きがどのように効果があるか友 検討寻る。

\section{方法}

被験体 雄のシロネズミ49匹（ただし条件づけ成立の基準に達したもののみで，除外した ものを入れると80匹になる)。実験開始時の体重は $130 \mathrm{~g} \sim 220 \mathrm{~g}$ であた。

装置 MOWRER-MILLER 型の回避訓練装置を使用した。すなわち長さ $79.3 \mathrm{~cm}$, 巾 $9.8 \mathrm{~cm}$, 高さ $23 \mathrm{~cm}$ の shuttle box で，床はグリッドになっており，装置の中央には高さ $4.8 \mathrm{~cm} の$ 仕切りがあって 2 部屋に分けられている。各部屋共 $100 \mathrm{~V} 5 \mathrm{~W}$ のランプで照明されている (真下のグリッド上の照度は60lux)。更にこの装置は長さ $97 \mathrm{~cm}$, 巾 $38 \mathrm{~cm}$, 高さ $73 \mathrm{~cm}$ のボ 一ド張りの防音箱(完全ではないが，相当の効果があると思われる)の中に入れられている。

この訓練箱には無条件刺激の電気衝撃を与えるための定電流装置, 条件刺激となる音の 発振器（松下電気製作の Model RC-2K の Audio-Frequency Oscillator）および防音箱 の中につ沙てあるスピーカー（アシダ音響製作の 6P-HF1)，また条件刺激之無条件刺激の 時間家自動的に調節する刺激器が接続されている。

手続き 1) 装置への馴れ。各被験体とも 1 日 1 回 5 分間, 連続 3 日間装置内に放置された。

2 ) 回避条件づけ。翌日から直ちに条件ゔけに入るが，条件刺激 (CS) は $2000 \mathrm{cps}$ の純音 (強度はスピーカー入力 $0.6 \mathrm{~V}$ ) であり, 無条件刺激(UCS) あった。CS-UCS間隔は 5 秒であり, shuttle box の中で一方の側から他方の側に被験体 が反応したときにCS, UCS ともに自動的に切れる。1 日20試行おこない，試行間隔は30 秒〜40秒で平均約 35 秒であった。条件づけ成立の基準は 20 試行中 18 試行，すなわち，90\%

Table 1. Summary of experimental procedure.

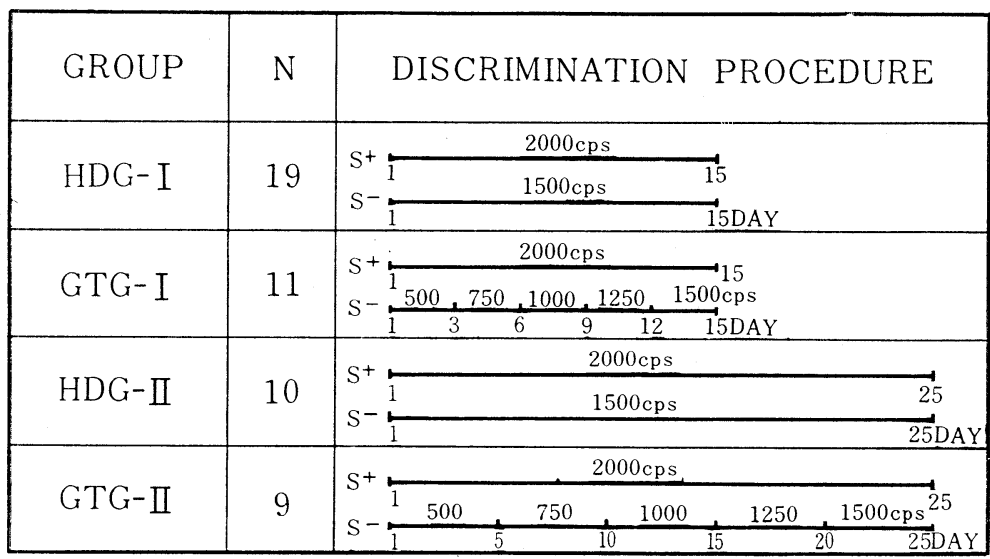


の回避反応成立までとした。ただし，10日以上たっても基準に達しない被験体は放棄した。

3 ）弁別訓練。条件ゔけが成立したならば，それに要した日数が各群同様になるように 被験体を 3 群に分け，翌日から弁別手続き に入った。各群とも 1 日 20 試行中, 10 試行 は正刺激 $\mathrm{S}^{+}(2000 \mathrm{cps})$ が与光られ，5秒以 内に反応しない場合には UCS が与光られ る。他の10試行は負刺激S一が与兄られる゙， これに対しては 5 秒以内に反応しない場合 は実験者が切り, UCS は与光られない。反 応した場合には $\mathrm{S}^{+}, \mathrm{S}^{-}$ともに反応と同時に 切れる。 $\mathrm{S}^{+}$と注ランダムに与えられ， 試行間隔注条件づけのときと同じであった。

各群のS-の与方方は次の通りである。

HDG-I 群：この群は LAWRENCEが Hard Discrimination Group といったもので弁 別訓練の最初から $1500 \mathrm{cps} の \mathrm{~S}^{-}$が使用さ れる。訓練期間の長さは 15 日間である。な おこの群の実験手続きは, 赤松・平井・春 木（1）の報告のうち $1500 \mathrm{cps}$ 群のものと 同一（但し, 馿れの日数が 1 日多く, 試行 間隔が 5 秒短い）であるため, 前報告のデ ーターを加えて結果を整理した。従って今 回の被験体数は 10 匹, 前回の分は 9 匹であ るため計19匹である。

HDG-II群 : HDG-I 群と同一で, 更に10日 間訓練を続行したものである。被験体数は 10匹である。

GTG-I群 : この群は LAWRENCEがGradual Transition Group といったもので, 弁別 訓練の最初はS-を并別容易な刺激とし, 次 第に困難なものに変化させて行く方法であ る。この群は $\mathrm{S}^{-を} 500 \mathrm{cps}, 750 \mathrm{cps}, 1000$ cps, $1250 \mathrm{cps}, 1500 \mathrm{cps}$ の 5 段階に分け, $500 \mathrm{cps}$ から，それぞれの刺激について 3 日 間づつ訓練して13日目で $1500 \mathrm{cps}$ に達する ようにする。被験体は11匹である。
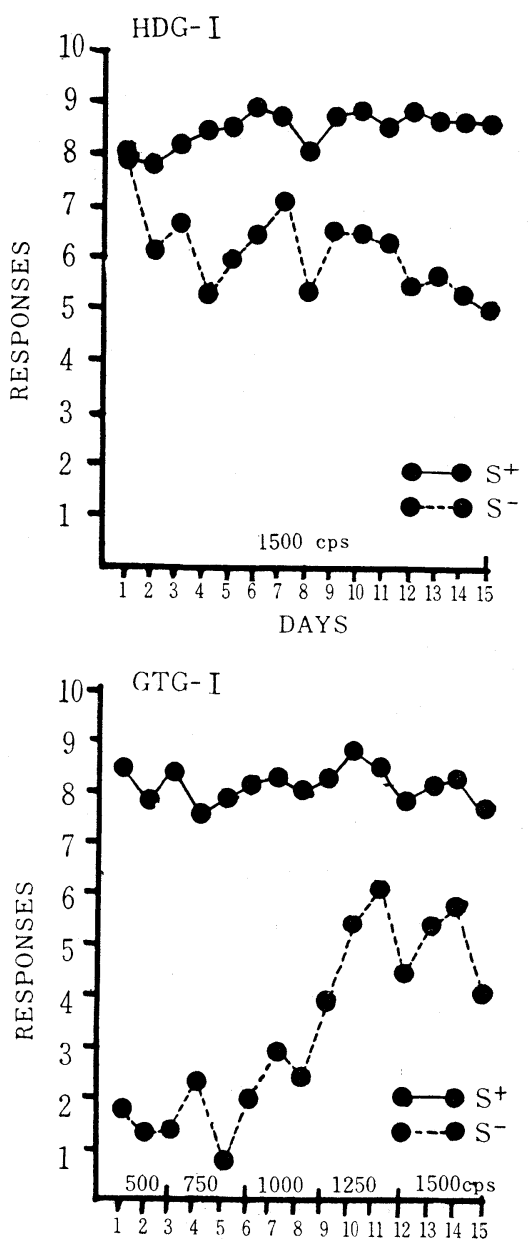

Fig. 1

Curves of discrimination learning for Hard Discrimination Group-I (HDG-I) and Gradual Transition Group-I (GTGI). $\mathrm{S}^{+}$and $\mathrm{S}^{-}$mean conditioned and discrimination stimulus, respectively. 

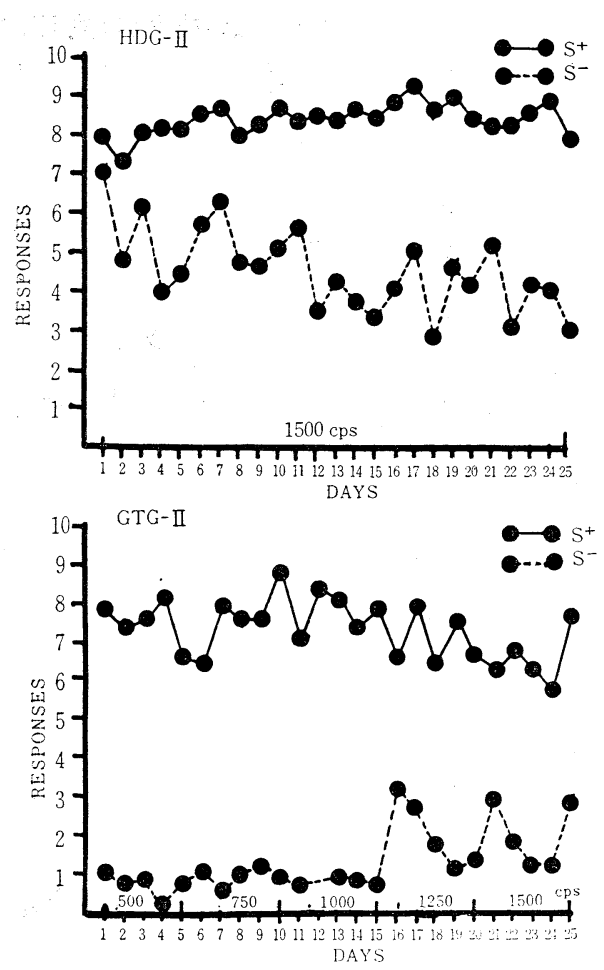

Fig. 2

Curves of discrimination learning for Hard Discrimination Group-II(HDG-II) and Gradual Transition Group-II (GTG-II).
GTG-II群 GTG-I 群と同一であ るが，一つの刺激について 5 日間 づつ訓練し,21日目で $1500 \mathrm{cps}$ に 達するようにする。被験体数は 9 匹である。群の構成については第 1 表に示されている。

\section{結果亡考察}

1) 条件ゔけに要した日数。

1 日20試行中 18 試行の回避に成 功するまでに要した各群の平均日 数について整理する。HDG-I 群 とGTG-I群，HDG-II群とGTG -II 群の夫々が比較の対象となる ので，それらの群間の平均日数に ついてみると.HDG-I群は5.9日 $(\mathrm{SD}=2.28)$, GTG-I 群は5.36日 $(\mathrm{SD}=2.11)$ であり，t検定の結果 差はみられなかった $(\mathrm{t}=0.678 \mathrm{df}$ $=28, \mathrm{P}<0.05)$ 。また HDG-II群壮 7.10日 $(\mathrm{SD}=2.21)$, GTG-II群将 6.33日 $(\mathrm{SD}=1.58)$ で, 検定の結 果これも差がタられなかった（t $=1.222, \mathrm{df}=17, \mathrm{P}>0.05)$ 。従 って, $\mathrm{S}^{+}$対する反応の強度は, それぞれ比較される群間において

は差がないと考えられる。それ故，次の弁別訓練の結果の群間の差異には条件づけの要因 は㗢かないものと考えてよい。

2 ) 各群の弁別学習成立の過程について。

各群の弁別学習の経過は第 1 図と第2 2図に示した通りである。HDG-I群は通常の弁別手 続きであり，弁別学習の経過も常にみられるところのものを示している。ただし，赤松・ 平井・春木 $(1)$ の報告のうち $1500 \mathrm{cps}$ 群の結果と比較してみると, 以前の結果では 2000 $\operatorname{cps}\left(\mathrm{S}^{+}\right)$と $1500 \mathrm{cps}\left(\mathrm{S}^{-}\right)$の間の差異が15日間ではあまり明確でないが，今回同一条件の被 験体を加えて結果を整理してみると， $\mathrm{S}^{+}$¿S一の間の差異がより明確になった。GTG-I群は 最初の $500 \mathrm{cps}, 750 \mathrm{cps}$ ，および $1000 \mathrm{cps}$ の-のときは，S-に対する反応が少なく，乙れも 赤松・平井・春木 $(1)$ の結果と同様に, シロネズミにおいては最初から感覚的に $2000 \mathrm{cps}$ 
とこれらの刺激の間の差異は明確で，汎化は少ないと考えられる。しかし，S-が $1250 \mathrm{cps}$ 以 上になると反応数が急激に増大している。

HDG-II群はHDG-I群と同様に通常の弁別手続きであり, 結果も同じ傾向を示しており, HDG-I群よりも弁別武行が多いため弁別がよりよく成立している。GTG-II群はGTG-I群 と同様に Sーが $500 \mathrm{cps} ら 1000 \mathrm{cps}$ まで注 Sーに対する反応数は少ない。乙かし $1250 \mathrm{cps}$ からは反応数が増大している。また興味のある事実は S-が $1250 \mathrm{cps}$ おび $1500 \mathrm{cps}$ の最 初の日は共にS-に対する反応は増大するが，5日間の試行の間に急激に反応数が減少し ている。ただし，最終日は反応数が多くなっているが，これは， $\mathrm{S}^{+}$の反応数も多くなって いるところから，何えらかの条件で活動水準が上ったためではないかと考えられる。また $\mathrm{S}^{-}$が $1000 \mathrm{cps}$ の時から $\mathrm{S}^{+}$に対する反応数が減少する傾向がみられる。これは $\mathrm{S}^{+}$に対し て， S-の負の汎化が影響を与えたと考えられる。

各群について升別が成立しているか否か みるために, 㚏別学習の最終期間, すなわ ち, HDG-I 群と GTG-I 群においては, 13日，14日，15日の最終 3 日間，HDG-II 群ふよび GTG-II群については21日から25 日までの 5 日間について, $\mathrm{S}^{+}$および Sーに 対する反応数の間に差があるか否かを検討 した結果, HDG-I 群については $\mathrm{t}=4.205$, $\mathrm{df}=112, \mathrm{P}<0.01, \mathrm{GTG}-\mathrm{I}$ 群については, コクラン・コックス法により検定したとこ ろ, to $=4.320>$ 基準 $\mathrm{t}=2.042, \mathrm{df}=64$ で 差染り, HDG-II 群についてほ同様に コクラン・コックス法で, to $=8.96>$ 基準 $\mathrm{t}=2.021, \mathrm{df}=88$ で差があり， GTG-II群 そついては, $\mathrm{t}=9.163, \mathrm{df}=88, \mathrm{p}<0.01 て ゙$, いゔれの群も差がタられ，弁別が成立して いることを礼ている。

このように各群とも $\mathrm{S}^{+}(2000 \mathrm{cps})$ と $\mathrm{S}^{-}$ (1500cps) の間の弁別が成立しているので， 升別手続きの差異による效果は群間での相 対的な比較になる。

3）弁別手続きの差異による弁別成立の 程度の比較。

弁別手続き上の差異が弁別の成立に如何 なる効果をおよぼしたかを検討するために，
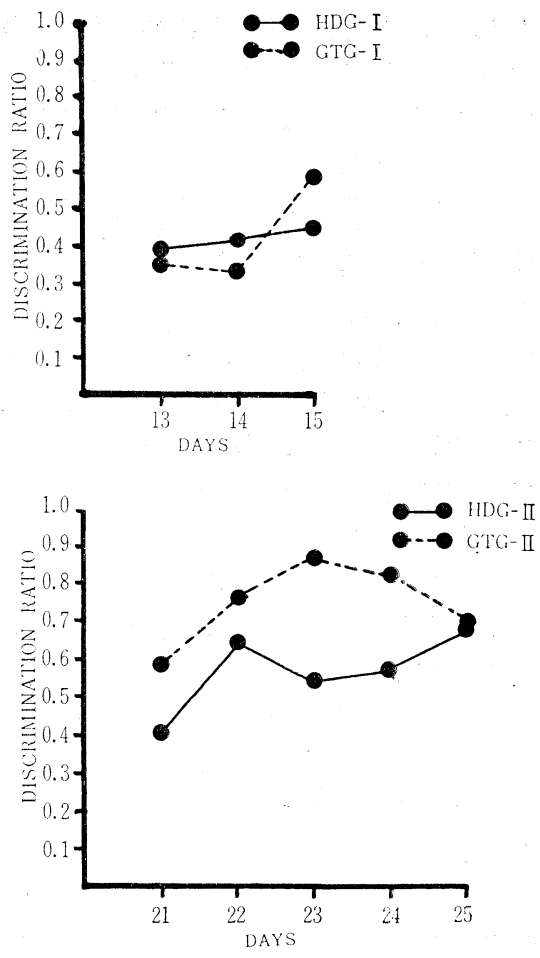

Fig. 3

Curves of discrimination ratio for four groups. 
$\mathrm{S}^{+}-\mathrm{S}^{-}$

$\mathrm{S}^{+}$を弁別率として, 并別の程度を表わす指標とした。この指標によるとその值が 1 に近いほどよく升別ができているということになる。各群の升別学習最終期間の平均弁別 率の経過第 3 図に示された通りである。

各群とも弁別学習最終期間全体の平均弁別率について，HDG-I群と GTG-I群，および HDG-II群と GTG-II群の間でそれぞれ両手続きの効果を比較してみる。

HDG-I 群の平均弁別率は 0.411 (SD=.36), GTG-I 群は 0.420（SD=0.33）で両群間 の $\mathrm{t}$ 検定の結果差がタられなかった $(\mathrm{t}=0.130, \mathrm{df}=88, \mathrm{P}>0.05)$ 。 $\mathrm{HDG}-\mathrm{II}$ 群の平均弁 別率核0.570(SD=0.35), GTG-II群は $0.742(\mathrm{SD}=0.29)$ で両群間の $\mathrm{t}$ 検定の結果， $5 \%$ の伦険率で差がみられた $(\mathrm{t}=2.561, \mathrm{df}=93,0.01<\mathrm{P}<0.05)$ 。

以上の結果から，どの実験群に関しても弁別の最終目標である $2000 \mathrm{cps}$ と $1500 \mathrm{cps}$ の間 の弁別は成立するが，并別手続きとして，弁別の最初から類似の刺激を用いて訓練するよ りも，最初は非常に異った刺激を用いて訓練をし，5 日間の段階で徐々に近づけて行く方 法が弁別の効率が高いことが分った。ただし，3 日間の段階で徐々に近づけてゆく手続き ではこの効果がない。これは各段階の刺激について 3 日間では弁別学習が成立しがたいた めと考えられる。

これらの結果については更に検討されるべき点がいくつかある。まず弁別の程度を表わ す指標について，乙の場合は $\frac{\mathrm{S}^{+}-\mathrm{S}^{-}}{\mathrm{S}^{+}}$を用いたが，この他 $\mathrm{S}^{+}-\mathrm{S}^{-}$のみを指標とすることも 考觉られる。この実験においてはこの指標については群間で差がみとめられなかった。從 て弁別率を示す指標のうちどれが最も適しているか検討を要する。

次に, 徐々に近づける方法に関して, 種々なる問題が提起され得るであうう。すなわち, この実験においては，各段階の期間の長さによって効果が異っているが，その他，徐々に 近づける段階の数によっても効果が異なると考光られる。これらの問題注 LAWRENCE (7) の実験で設けられたもう一つの手続き，すなわち，異った刺激の升別から突然困難な刺激 に変化させる手続きと関連させて，段階の数之段階の期間の長さの相互的な関連の下に， 徐々に近づける方法がいかに有効であるか，更に詳細な要因について分析を必要とすると 考えられる。

問題はのこされているが，ここで得られた実験結果は基本的には PAVLOVやLAWRENCEの 結果と一致するものである。それならばこの方法が何故効果があるのか問題になるが， PAVLOVはこれについては何も説明していない。LAWRENCE は，この結果はS-R 理論にも とずく刺激汎化勾配の考光を発展させた形で説明できるが，彼自身の理論である acquired distinctivness of cues の考元方で説明した方がよいと指摘している。この実験結果もこの 概念で説明できないことはないが, 使用した装置の刺激事態や $\mathrm{S}^{+} や \mathrm{~S}^{-}$は極めて単純な刺激 であることから，cue dominanceの考光方よりも，HARLOW（3）の learning set，宋た は最近の LAWRENCE（8）の概念である coding response で説明した方がよいかもしれな い。第 2 図の GTG-II 群の $1250 \mathrm{cps}$ および1500cpsに対する反応数の経過洼，最初の日は反 
応数がいずれも多いが，5日間の間に急激に減少しており，わずかではあるが，1500cps の最初の日の反応数が $1250 \mathrm{cps}$ のそれよりも少ない傾向がある。これは learning set の曲 線を思わせる。又このいずれの場合も S一に対する反応数の水準は HDG-II 群の最初の日 の反応水準よりずっと低いことは，これらの刺激まで徐々に近づけてくる手続きの間に被 験体に対して，Sーに対しては反応しないという coding responseが成立したのではないか と思わせるのに充分である。

以上のようにこの現象は種々なる概念によって説明できそうであるが，この報告では理 論の検討は目的としていないので, 今後の問題として残される。

要 約

回避条件づけにおける升別は理論的に通常の手続きではとの成立が困難なのではないか と推測されている。一方 PAVLOV や LAWRENCE によれば弁別は最初非常に異った刺激の間 で行い，徐々に類似した刺激に近づけて行くと容易であるという事実索報告している。そ こで回避条件づけの弁別にもこの事実があてはまるか不か検討したものである。2000 cps の条件刺激に刘して条件づけが成立したならば，一群は通常の弁別手続きのように直ちに 升別刺激の $1500 \mathrm{cps}$ 与光, 最初から $2000 \mathrm{cps}$ との間の弁別訓練を受けるが, 他方の群は最 初は500cps の刺激との間の弁別訓練を受け，250cps の段階で徐々に $1500 \mathrm{cps}$ まで近づけら れてゅく。この際 3 日間づつの期間で段階が変って行く群と 5 日間づつの期間で段階が変 るものとが設けられた。結果の比較は弁別学習の最終段階における $2000 \mathrm{cps}$ と $1500 \mathrm{cps}$ との 間の弁別が両手続きによってどのように異なるかをみることであるが，5 日間の期間で異 なった刺激から徐々に近づけて行く手続きが通常の升別手続きよりも效果があることが確 められた。これはPAVLOVやLAWRENCE の結果と一致する。この現象についての説明につい て若干の考察をした。

\section{REFERENCES}

1. 赤松保羅・平井久・春木豊 回避反応の研究(10)一一回避条件ゔけにおける分化, 日本心理学会第25回大会発表論交集, 1961

2. 赤松保羅・平井久・春木豊 回避反応の研究(12) 一一回避条件ら゙けの分化における UCSの強度について, 日本心理学会第26回大会発表論交集, 1962

3. Harbow, H. F. The formation of learning sets. Psychol. Rev., 1949, 56, $51 \sim 65$.

4. 春木豊・平井久 回避反応の研究(13)一一回避条件づけにおける弁別の手続き, 日 本心理学会第27回大会発表論文集, 1963.

5. 平井久・春木豊・酒井誠 回避行動に関する研究，心研，1961，32，232２53.

6. Hoffeld, D. R. Primary stimulus generalization and secondary extinction 
as a function of strength of conditioning. J. comp. physiol. Psychol., 1962, $55,27 \sim 31$.

7. Lawrence, D. H. The transfer of a discrimination along a continum. J. comp. physiol. Psychol, 1952, 45, 511 516.

8. Lawrence, D. H. The nature of a stimulus: Some relationships between learning and perception. In S. Koch (ed.) Psychology: A study of sc ience, Vol. 5, 1963, New York: McGraw-Hill.

9. Miller, W. C., \& Greene, J.E. Generalization of an avoidance response to various intensities of sound. J. comp. physiol. Psychol., 1954, 47,136 139.

10. 宮田 洋 逃避および回避反応における刺激汎化，心研，1956，26，320～325.

11. Pavlov, I. P. Conditioned Reflexes. (Translated by G. V. AnreP). London: Oxford University Press. 1927.

12. Trompson, R.F. Primary stimulus generalization as a function of acquisition level in the cat. J. comp. physiol. Psychol., 1958, 51, 601 606. 


\title{
Abstract \\ A Comparison of Two Discrimination Procedures in Avoidance Conditioning in the White Rat.
}

\author{
Yutaka Haruki and Bunichiro Ishi \\ Waseda University
}

It is theoretically inferred that the discrimination in avoidance conditioning is difficult in typical discrimination procedure when two stimuli to be discriminated are very similar. PAVLOv and LAWRENCE have reported that a difficult discrimination between two quite similar stimuli is more efficient when subjects are first trained on an easy discrimination between two dissimilar stimuli and then gradually approach the difficult one than if all the training is given directly on the difficult discrimination. The purpose of this experiment is to compare the efficiency of these two procedures on discrimination in avoidance conditioning.

Method Subjects: The $S$ s were 49 male albino rats. Apparatus: The apparatus was the modified Mowrer-Mlluer shuttlebox. Procedure: After the establishment of avoidance conditioning to the CS which was $2000 \mathrm{cps}$ tone, dicrimination training started. Hard Discrimination Group-I (HDG-I) was trained on the discrimination between $2000 \mathrm{cps}\left(\mathrm{S}^{+}\right)$and $1500 \mathrm{cps}$ tone $\left(\mathrm{S}^{-}\right)$throughout 15 days. Hard Discrimination Group-II (HDG-II) was given the same procedure as HDG-I, but training was continued for 25 days. Gradual Transition Group-I (GTG-I) started on the discrimination between $2000 \mathrm{cps}$ and $500 \mathrm{cps}$ tone $\left(\mathrm{S}^{-}\right)$ and then the $\mathrm{S}^{-}$gradually approached the $1500 \mathrm{cps}$ tone through a series of graduated steps. The $\mathrm{S}^{-}$rose to $1500 \mathrm{cps}$ by giving $250 \mathrm{cps}$ every three days. Gradual Transition Group-II (GTG-II) was giving the same procedure as GTG-I, but the $\mathrm{S}^{-}$rose every five days (See Table 1 ).

Results 1). The discrimination curves for each group are shown in Fig. 1 and 2. There was statistically significant difference between the number of responses to the $\mathrm{S}^{+}$and $\mathrm{S}^{-}$at the last step of discrimination training for each group. This means that discrimination between $\mathrm{S}^{+}$and $\mathrm{S}^{-}$was established for each group. 2). In order to make comparisons between groups, discrimination ratios $\left(\mathrm{S}^{+}-\mathrm{S}^{-} / \mathrm{S}^{+}\right)$were calculated as an indicator of discrimination learning. Curves of them in the last training step for four groups are presented in Fig. 3. As a result of statistical comparisons between groups on these ratios, no significant difference was shown between HDG-I and GTG-I, but between HDG-II and GTG-II. This suggests that the difficult discrimination between two very similar stimuli in avoidance conditioning was more efficient when subjects approached the difficult discrimination through a series of graduated steps than if all the training was given directly on the difficult one. This also suggests that one of the important factors for this effect was the duration of a step, that is to say, this effect was not obtained in case of the short duration of a step. 